\title{
Toxicity of Drilling Waste from Oil Wells on Oligochaeta
}

\author{
Hugo Maia Machado ${ }^{1}$, Nelson Moura Brasil do Amaral Sobrinho ${ }^{1}$, \\ Maria Elizabeth Fernandes Correia ${ }^{2}$, Marcio Osvaldo Lima Magalhães ${ }^{3}$, \\ Erica Souto Abreu Lima ${ }^{1}$ \\ ${ }^{1}$ Universidade Federal Rural do Rio de Janeiro - UFRRJ, Seropédica/RJ, Brasil \\ ${ }^{2}$ Centro Nacional de Pesquisa de Agrobiologia, Empresa Brasileira de Pesquisa Agropecuária - Embrapa Agrobiologia, \\ Seropédica/RJ, Brasil \\ ${ }^{3}$ Universidade do Estado de Mato Grosso - UNEMAT, Tangará da Serra/MT, Brasil
}

\begin{abstract}
The most abundant and critical elements in residues from well drilling and prospecting are barium and sodium. Ecotoxicological tests have been used to evaluate the toxicity caused by toxic substances present in the soil. The objective of the present study was to verify the effect of the application of drilling residue from oil wells on Oligochaeta activity. After incubation of the soil with residue doses $-\mathrm{BaSO}_{4}$ and $\mathrm{NaCl}$ - three ecotoxicological tests were performed in which the species Eisenia andrei was used as a bioindicator. The avoidance behavior test showed that there was a negative effect of the application of the residue at a dose of $234 \mathrm{tha}^{-1}$ on Oligochaeta activity. However, the application of $\mathrm{BaSO}_{4}$ alone did not show damage to the earthworms, unlike what was observed for $\mathrm{NaCl}$ application. These results indicate that sodium was the element that most restricted the activity of these organisms.
\end{abstract}

Keywords: ecotoxicology, soil contamination, sodium, barium, Eisenia Andrei. 


\section{INTRODUCTION}

Materials and waste associated with the drilling and prospecting for oil wells have a potential impact on the environment, which depends on the material's composition and on the biotic community to which they are exposed (Ekpo \& Uzegbu, 2004; Magalhães et al., 2016). Among the residues generated when drilling for oil wells, drilling waste stands out due to the large volume generated and the potentially toxic elements produced (Bauder et al., 2005; Magalhães et al., 2012, 2014a). These residues are generated by mixing the fluid, which is an oil-water emulsion with colloidal matter (which may include bentonite, $\mathrm{BaSO}_{4}$, and sodium chloride, among other additives), and ground rock (Darley \& Gray, 1988). The effects of applying drilling waste on soil have been investigated (Lima et al., 2012; Magalhães et al., 2014b) and have shown that the elements barium, in reducing conditions, and sodium (Freitas et al., 2015) are the most limiting for the growth of several crops, including rice (Magalhães et al., 2012), sunflower (Sampaio et al., 2015), and Brachiaria (Andrade et al., 2014). However, there are few studies that show the effects on soil invertebrates of applying drilling waste. In recent years, ecotoxicological tests have been carried out to evaluate contaminated areas or the effect of the application of substances on the soil (Langdon et al., 2003; Owojori \& Reinecke, 2009; Guzyte et al., 2011). These tests indicate the toxicity of the substances present in contaminated soils (Wu et al., 2012). In tests using soil invertebrates, earthworms are generally used as the target species because they are widely available, easily bred in the laboratory, and reproduce rapidly and consistently (Gomez-Eyles et al., 2009). Several organizations such as the ISO, USEPA and Organization for Economic Cooperation and Development (OECD) have developed protocols that use earthworms to assess the effects of soil contaminants on invertebrate communities. The objective of this study was to evaluate the effect of the application of drilling waste on soil earthworm (Eisenia andrei) activity through the study of behavior, chronic effects (reproduction) and deleterious effects.

\section{MATERIALS AND METHODS}

The evaluation consisted of two tests: one behavioral (avoidance) and one toxicity test (chronic toxicity and acute toxicity). In both tests, earthworms
(Oligochaeta) of the Eisenia andrei species, weighing between 250 and $600 \mathrm{mg}$, were used.

For the study, material collected during the drilling of an oil well located in the state of Bahia, Brazil, was used. Samples were collected from the waste pile generated by "waste dryer" equipment. The soil samples were collected at a depth of 0-20 cm, from a Red-Yellow Dystrophic Argisol, which was representative of the area surrounding the drilling site. The preparation of the soil samples consisted of soil air-drying, loosening of the soil, and soil sieving with 4-mm sieves for the substrate and 2-mm sieves for the soil analysis. The residue was also submitted to the same preparation as the soil.

The collected soil had a barium concentration of $317 \mathrm{mg} \mathrm{kg}^{-1}$ (USEPA, 2007); a pH value in water of 4.4; exchangeable bases $\left(\mathrm{Na}^{+}, \mathrm{Ca}^{2+}, \mathrm{Mg}^{2+}\right.$ and $\left.\mathrm{K}^{+}\right)$of $0.04,0.9$, 0.4 , and $0.01 \mathrm{cmol}_{c} \mathrm{dm}^{-3}$, respectively; exchangeable $\mathrm{Al}$ of $3.5 \mathrm{cmol}_{c} \mathrm{dm}^{-3} ;$ potential acidity $(\mathrm{H}+\mathrm{Al})$ of $4.1 \mathrm{cmol}_{c} \mathrm{dm}^{-3}$; organic carbon content (Corg) of $6.30 \mathrm{~g} \mathrm{~kg}^{-1}$; organic matter (OM) of $10.86 \mathrm{~g} \mathrm{~kg}^{-1}$; clay of $420 \mathrm{~g} \mathrm{~kg}^{-1}$; and a cation exchange capacity (CEC pH 7.0) of $5.6 \mathrm{cmol}_{c} \mathrm{dm}^{-3}$ (Donagemma et al., 2011).

In the collected residue, the pseudo-total levels (USEPA, 2007) of arsenic $\left(2.4 \mathrm{mg} \mathrm{kg}^{-1}\right)$, barium $\left(25.6 \mathrm{~g} \mathrm{~kg}^{-1}\right)$, lead $\left(6.5 \mathrm{mg} \mathrm{kg}^{-1}\right)$, iron $\left(27.7 \mathrm{~g} \mathrm{~kg}^{-1}\right)$, manganese $\left(359 \mathrm{mg} \mathrm{kg}^{-1}\right)$, zinc (44.6 mg kg-1), calcium $\left(3.1 \mathrm{~g} \mathrm{~kg}^{-1}\right)$, magnesium (11.6 $\left.\mathrm{g} \mathrm{kg}^{-1}\right)$, sodium $\left(10.9 \mathrm{~g} \mathrm{~kg}^{-1}\right)$ and potassium $\left(1.4 \mathrm{~g} \mathrm{~kg}^{-1}\right)$ were determined. The organic carbon content was also quantified ( $440 \mathrm{~g} \mathrm{~kg}^{-1}$ ) according to the EMBRAPA Manual of Methods of Soil Analysis (Donagemma et al., 2011).

An "artificial" soil composed of $70 \%$ washed sand, $20 \%$ kaolin and $10 \%$ peat was also used according to a protocol suggested by the Organization for Economic Cooperation and Development (OECD, 1984). The $\mathrm{pH}$ of the artificial soil was adjusted to close to 6 , with a variation of $\pm 0.5 \mathrm{pH}$ units. For the soil $\mathrm{pH}$ correction, a neutralization curve was performed, where the amount of $\mathrm{CaCO}_{3}$ to be added to reach the $\mathrm{pH}$ value proposed in the study was determined.

The behavioral test (avoidance) was based on the OECD (1984) and ISO 238 (ISO, 2003). The completely randomized experimental design consisted of three doses of each of the three contaminants (waste, $\mathrm{BaSO}_{4}$ and $\mathrm{NaCl}$ ), plus a control treatment, with five replications, totaling 50 experimental units. 
Soil samples were incubated with three doses of the drilling waste, equivalent to 23.4234 , and $468 \mathrm{Mg} \mathrm{ha}^{-1}$ at a depth of $0.2 \mathrm{~m}$. The waste doses were based on guideline values for barium, according to CONAMA (Brasil, 2009), that is, waste doses to reach 300,3000 and $6000 \mathrm{mg} \mathrm{kg}^{-1}$ of $\mathrm{Ba}$ (which correspond to the value of investigation (VI), 10 times VI, and 20 times VI, respectively). Because barium and sodium are the most abundant elements present in the drilling waste (Magalhães, 2011), to evaluate the isolated effects of barium and sodium, the samples were also incubated with three barium doses in the form of $\mathrm{BaSO}_{4}$ $\left(300,3000\right.$ and $\left.6000 \mathrm{mg} \mathrm{kg}^{-1} \mathrm{Ba}\right)$ and three doses of sodium in the form of $\mathrm{NaCl}\left(324.8,1277\right.$ and $\left.3248 \mathrm{mg} \mathrm{kg}^{-1} \mathrm{NaCl}\right)$, considering the amount of sodium that was applied at the different waste doses $\left(127.7,1277\right.$, and $\left.2554 \mathrm{mg} \mathrm{kg}^{-1} \mathrm{Na}\right)$.

The experimental units were composed of plastic boxes $(21 \mathrm{~cm} \mathrm{x} 15 \mathrm{~cm} \times 8 \mathrm{~cm})$, which were divided into two sections of equal size by a plastic spatula. One of the sections was filled with $450 \mathrm{~g}$ of soil from the environment without any treatment (natural soil), and the other was filled with the same amount of soil treated with the different doses of the waste, $\mathrm{BaSO}_{4}$ and $\mathrm{NaCl}$. At the end of filling, the spatula was removed, and 10 synchronized earthworms with individual masses of 250 - $600 \mathrm{mg}$ were placed on the dividing line. The assay was conducted in an air-conditioned environment for 48 hours. After this period, the boxes were again divided into two sections to record the number of earthworms in each section. It should be noted that during the test, the soil was maintained at a moisture level equivalent to $60 \%$ of field capacity.

This test assumes an equitable distribution when two sections of the experimental unit are filled with the same soil type (Hund-Rinke \& Wiechering, 2001). Therefore, validation was performed for the avoidance test by including a control treatment that had only natural soil on both sides of the experimental unit, thus demonstrating deviations in distribution whose cause was not the addition of waste. A maximum mortality level determined by the protocol to be 10\% (OECD, 1984) was also assumed. The protocol also suggests that the escape by more than $80 \%$ of individuals indicates a contaminated environment.

The "artificial soil" toxicity test was based on two tests: the acute toxicity test (mortality test) and the chronic toxicity test (reproduction test).
The acute toxicity test (mortality test) aims to determine the lethal dose of a given waste or contaminant that kills $50 \%$ of the earthworm population (LD50). This test was based on guidelines from the "Organization for Economic Cooperation and Development (OECD)" Guide to Chemical Testing No. 207 (OECD, 1984). On the other hand, the chronic toxicity test (breeding test) aims to determine the dose of the residue that presents the greatest potential to interfere with earthworm reproduction. This followed the International Standard Organization's evaluation method - effects of pollutants on earthworms and determination of their effect on reproduction (ISO, 1997).

In the test, "artificial soil" was used to isolate the effect of the residue on earthworms, since this method is considered standard to evaluate the intrinsic toxicity of substances and residues.

The experimental design was completely randomized, consisting of six waste doses and a control treatment (soil without waste), with four replications.

To determine the doses of the residue, a geometric progression was performed based on six doses of barium: $300,900,1500,2100,2700$, and $3000 \mathrm{mg} \mathrm{kg}^{-1} \mathrm{Ba}$, which correspond, respectively, the value of investigation for barium, and to 3, 5, 7, 9 and 10 times this value. To achieve the respective barium concentrations, it was necessary to apply the following residue doses: 23.4, 70.2, 117.0, 163.8, 210.6, and 234.0 $\mathrm{Mgha}^{-1}$.

The test consisted of adding 500 grams of soil treated with different doses of the residue and a control treatment (artificial soil without residue) to the experimental units (500 ml opaque plastic containers - pots of the type used to store honey), forming a $7 \mathrm{~cm}$ soil layer. During the test, moisture was maintained at $60 \%$ of field capacity. For each unit, 10 earthworms were weighed and allocated. Synchronized earthworms were used so that they all had an age difference of no more than 30 days, according to the established protocol (ISO, 1997).

After 28 days, the earthworms were removed, leaving only the cocoons. The cocoons were left for another 28 days, after which the number of juveniles in each experimental unit was counted. The earthworms were weighed on the first, seventh and fourteenth days. The number of dead earthworms was recorded in the different treatments to detect which residues doses would lead to the death of $50 \%$ of the earthworms (LD50), 
thus taking advantage of a single test to perform both the chronic toxicity test and the acute toxicity test. The following were also determined: the highest dose of the No Observed Effect Concentration (NOEC), which represents the maximum dose of a chemical compound for which no effects were observed; the Lowest Observed Effect Concentration/Level (LOEC), which represents the lowest dose at which effects are observed; and the effective lethal concentration to prevent reproduction of $50 \%$ of individuals (EC 50).

The following statistical analyses were performed: an analysis of variance and a comparison of the data using Fisher's test at 5\% probability for the behavioral test - this test allows a comparison of the distribution of the worms, in relation to an expected distribution, assuming avoidance behavior does not exist for a particular type of soil - and Dunnet's test $(\rho<0.05)$ for the acute toxicity test. All statistical analyses were done using STATISTIC Software Version 7.0. Lethal concentration values (EC50) were calculated using the Logistic model.
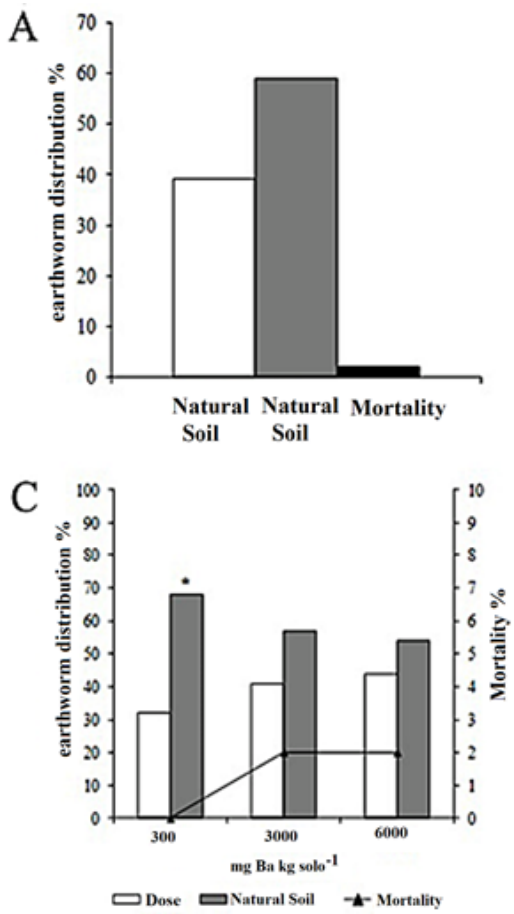

The avoidance behavior test that was carried out can be considered valid because it was observed that in the control treatment, there was no preference for earthworms on either side, thus presenting an equitable distribution. This was demonstrated by the result of the Fisher test, which did not show a significant difference $(\mathrm{P}<0.05)$ for earthworm preference for either side containing natural soil (Figure 1A). This showed that, deviations in the distribution of earthworms were caused by addition of waste.

However, for all doses of sodium chloride, more than $80 \%$ of the earthworms escaped to the natural soil side (Figure 1B), with avoidance behavior percentages of 84,96 and $92 \%$, respectively, for doses of 127,1277 and $2554 \mathrm{mg} \mathrm{kg}^{1}$ of $\mathrm{Na}$. This demonstrated the sensitivity of the earthworms to sodium, which, in high doses, causes physiological damage. Owojori \& Reinecke (2009), working with artificial soil and with different doses of sodium chloride, found that from the dose of $2000 \mathrm{mg} \mathrm{NaCl} \mathrm{kg}^{-1}$ of soil, the escape of
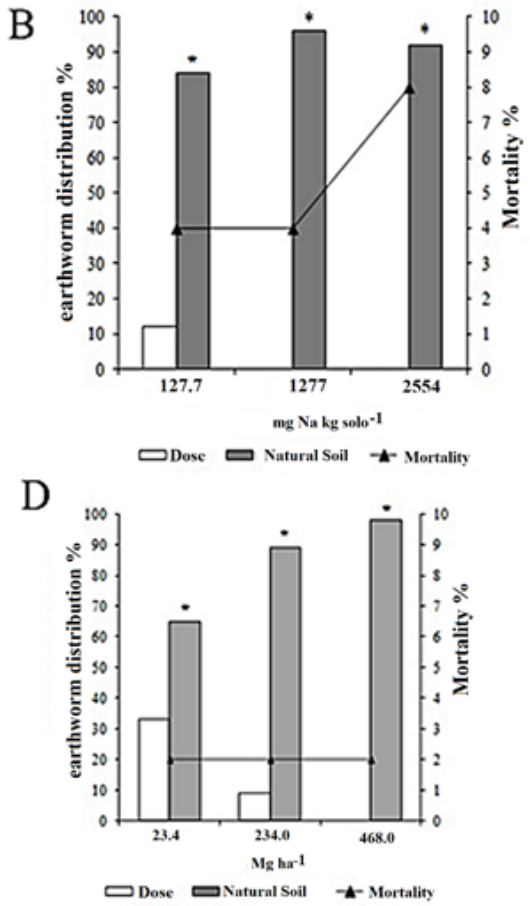

Figure 1. Distribution of earthworms in the control and at different contaminant doses: (A) Control; (B) NaCl; (C) $\mathrm{BaSO}_{4}$ and (D) waste. ${ }^{*}$ significant difference ( $\mathrm{p} \leq 0.05$ by Fisher's test) of the dose when compared to the natural soil for the escape of the earthworms. 
the earthworms to the artificial soil was above $80 \%$, which is considered an environment refractory to these organisms (OECD, 1984). Although the $\mathrm{NaCl}$ values applied to the soil at dose 1 were lower than the concentrations studied by Owojori \& Reinecke (2009), escape behavior higher than $80 \%$ was observed for the natural soil at that dose, i.e., a small amount of sodium was enough to cause damage to the organisms.

This pronounced impact, observed in the $\mathrm{NaCl}$ doses in the respective tests, is possibly associated with the characteristics of the soils studied. In this study, we used samples of a Red-Yellow Dystrophic Argisol with low OM; however, the authors mentioned used artificial soil containing $10 \%$ peat, so that more sodium was retained, causing less deleterious effects on the earthworms. Ellis et al. (2007) reported that one of the attributes of the soil that decreased the toxicity of carbendazim was the OM content due to the increase of soil CEC.

For treatments that only used $\mathrm{BaSO}_{4}$ (Figure $1 \mathrm{C}$ ), escape behavior above $80 \%$ at the doses studied was not observed, indicating the low toxicity level of this compound. Lima et al. (2012) verified that the application of up to $3000 \mathrm{mg} \mathrm{kg}^{-1}$ of Ba did not interfere in the development of rice plants. Similar results were observed by Magalhães et al. (2012) using barium sulfate as the source of contamination.

However, in treatments with drilling waste (Figure 1D), there was a statistically significant movement toward the natural soil at all doses. At the lowest residue dose, $65 \%$ of the earthworms were found in the natural soil, which did not exceed the $80 \%$ proposed by the OECD (1984). However, at doses 2 and 3, the escape to the natural soil was 89 and $98 \%$, respectively, demonstrating that these doses were highly restrictive for earthworms and indicating potential toxicity due to the application of this residue on the soil. Barium is an element toxic to organisms. However, the barium present in drilling waste takes the form of barium sulfate, which has low solubility and, consequently, low toxicity, as has already been observed in several plants (Lima et al., 2012; Magalhães et al., 2012; Andrade et al., 2014; Sampaio et al., 2015).

These results indicate that sodium was possibly the most restrictive element in the application of the soil residue, since the same sodium concentrations used for the sodium chloride test were present at the respective doses for the drilling waste. The treatment with $\mathrm{BaSO}_{4}$ verified this hypothesis because it did not show toxicity to earthworms, since the concentrations were the same at the different doses of drilling waste (300, 3000 and $\left.6000 \mathrm{mg} \mathrm{Ba} \mathrm{kg}^{-1}\right)$.

In the acute toxicity test with artificial soil, it was not possible to calculate the LD50 because there was no death or escape of earthworms at any dose. Guzyte et al. (2011), working with artificial soil and testing different $\mathrm{NaCl}$ doses, observed that total earthworm mortality was observed at the dose of $6000 \mathrm{mg} \mathrm{NaCl}$ per $\mathrm{kg}$ of soil, and the LD50 was $5623 \mathrm{mg} \mathrm{NaCl}$ per $\mathrm{kg}$ of soil. At the highest waste dose $\left(234 \mathrm{Mg} \mathrm{ha}^{-1}\right)$, the $\mathrm{NaCl}$ concentration was $3248 \mathrm{mg} \mathrm{kg}^{-1}$ soil. When compared to the results obtained by Guzyte et al. (2011), this value was below the amount necessary to cause the death of the earthworms. At doses of 117.0, 163.8, 210.6, and $234.0 \mathrm{Mg}$ of waste ha ${ }^{-1}$, the earthworms moved to the surface and adhered to the wall of the experimental units, reducing the feed and consequently presenting weight reduction, which was a form of adaptation (resistance) developed for this hostile environment. Langdon et al. (2003), studying earthworms Lumbricus rubellus, observed that the earthworms created resistance to arsenic and showed the behavioral reactions of winding, rejection, escape to the surface or interruption of feeding.

When the weight of the earthworms on the first and fourteenth days are compared, there is an increase of 12.1 and $1.2 \%$ in the control and at dose 1 , respectively. However, weight reductions of $4.4,6.7,13.3,19.7$ and $21.6 \%$ were observed at doses $2,3,4,5$, and 6 , respectively (Figure 2). These results clearly demonstrate that from the second dose, the waste interfered with earthworm feeding, possibly due to the high salt content present at these doses. The amount of residue applied was not sufficient to cause the immediate death of the earthworms, but they lost weight, indicating inhibition of feeding.

The average earthworm production in the control was 40 juveniles; however, at dose 1 , the mean production was 6.5 , corresponding to a reduction in juvenile production of $83.75 \%$. This dose corresponds to the application of $23.4 \mathrm{Mg} \mathrm{ha}^{-1}$ of the waste and, consequently, $128 \mathrm{mg} \mathrm{kg}^{-1} \mathrm{Na}$ (Figure 3).

From dose 2, there was no juvenile production, due to the amount applied, and, consequently, to the high 
sodium content. NOEC, which refers to the highest dose without an observed effect, could not be calculated, since the first applied dose was high enough to show a reduction in the production of juveniles. However, the NOEC is between 0 and $23.4 \mathrm{Mg} \mathrm{ha}^{1}$, and new tests with lower concentrations are required to determine this parameter. The LOEC, which represents the lowest observed dose, was dose 1, and it was the only dose where there was juvenile production. The effective concentration of waste to inhibit the production of $50 \%$ juveniles (EC 50) was $20.91 \mathrm{Mg} \mathrm{ha}^{1}$. These results confirm those obtained in the tests previously discussed, where sodium was the element that produced the greatest restriction after application of waste.

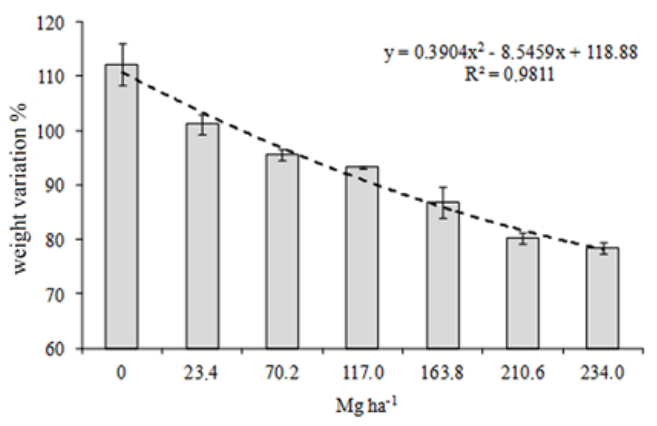

Figure 2. Variation in the weight of the earthworms between the first and the fourteenth day after application of different doses of drilling waste.

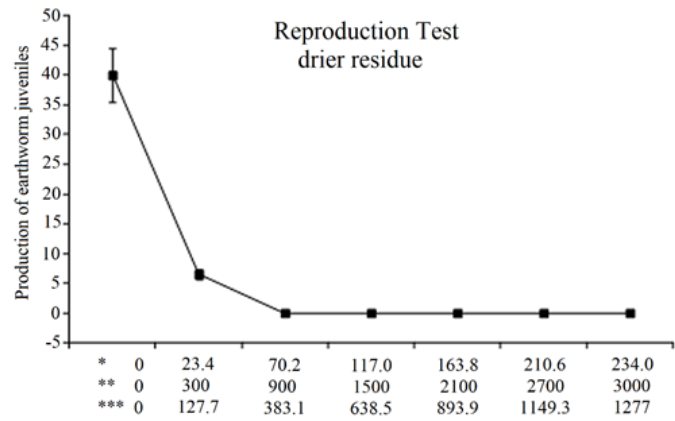

Figure 3. Mean production of earthworm juveniles in the drilling waste. $\left(^{*}\right)$ application of the waste in $\mathrm{Mg} \mathrm{ha}^{-1}$ at a depth of $20 \mathrm{~cm} ;\left(^{\star *}\right)$ Barium levels in $\mathrm{mg} \mathrm{kg}^{-1}$ of soil and $\left.{ }^{* * *}\right)$ levels of sodium in $\mathrm{mg} \mathrm{kg}^{-1}$ of soil.
Owojori \& Reinecke (2009) also observed the adverse effect of salinity with a decrease in juvenile production, although the residue amount applied was significant and may have intensified the action of this element. Owojori et al. (2008) worked with artificial soil and tested different $\mathrm{NaCl}$ doses to determine the concentration of $\mathrm{NaCl}$ required to inhibit the production of juveniles by $50 \%\left(\mathrm{EC}_{50}\right)$. They found that $2020 \mathrm{mg}$ of $\mathrm{NaCl} \mathrm{kg}^{-1}$ of soil was the amount needed to inhibit reproduction by $50 \%$ and concluded that $\mathrm{NaCl}$ concentrations that were not toxic for plants could still cause toxicity to earthworms.

\section{CONCLUSIONS}

In the behavioral test, the application of the drilling waste to the soil was restrictive from the dose of $234.0 \mathrm{Mg} \mathrm{ha}^{-1}$. Sodium was the element present in the most limiting waste, when applied to soils.

The highest amount of residue applied (234 $\left.\mathrm{Mg} \mathrm{ha}^{1}\right)$ was not sufficient to cause the death of $50 \%$ of the individual earthworms; however, it led to a reduction in earthworm weight.

The effective concentration of residue found to inhibit the production of $50 \%$ of juveniles (EC 50) was $20.91 \mathrm{Mg} \mathrm{ha}^{-1}$.

\section{ACKNOWLEDGEMENTS}

The authors would like to thank the Fundação de Amparo à Pesquisa do Estado do Rio de Janeiro (FAPERJ) and the Conselho Nacional de Desenvolvimento Científico e Tecnológico (CNPq).

\section{SUBMISSION STATUS}

Received: 27 sep., 2017

Accepted: 26 oct., 2017

\section{CORRESPONDENCE TO}

\section{Erica Souto Abreu Lima}

Departamento de Solos, Universidade Federal Rural do Rio de Janeiro - UFRRJ, Br 465, Km 7, CEP 23897-000, Seropédica, RJ, Brasil e-mail: ericaabreulima@gmail.com 


\section{REFERENCES}

Andrade AFM, Amaral Sobrinho NMB, Santos FS, Magalhães MOL, Becerra AT, Lima LS. EDTA-induced phytoextraction of lead and barium by brachiaria (B. decumbens cv. Basilisk) in soil contaminated by oil exploration drilling waste. Acta Scientiarum Agronomy (Impresso) 2014; 36(4): 495-500. http://dx.doi.org/10.4025/ actasciagron.v36i4.18172.

Bauder TA, Barbarick KA, Ippolito JA, Shanahan JF, Ayers $\mathrm{PD}$. Soil properties affecting wheat yields following drillingfluid application. Journal of Environmental Quality 2005; 34(5): 1687-1696. http://dx.doi.org/10.2134/jeq2004.0384. PMid:16091622.

Brasil. Conselho Nacional de Meio Ambiente. Resolução CONAMA n. 420, de 28 de dezembro de 2009. Diário Oficial da República Federativa do Brasil, Brasília, DF (2009); Sec: 81-84.

Darley HCH, Gray GR. Composition and properties of drilling and completion fluids. 5th ed. Houston: Gulf Publishing Company, 1988.

Donagemma GK, Campos DVB, Calderano SB, Teixeira WG, Viana JHM. Manual de métodos de análise de solos. 2 ed. Rio de Janeiro: Embrapa Solos; 2011. (Embrapa Solos. Documentos; no. 132).

Ekpo MA, Uzegbu ML. The effect of the petroleum drilling mud additive (chromelignosulphonate) on the microbiology and survival of periwinkle (Pachymelania spp. and Tympanotonus sp.). World Journal of Microbiology \& Biotechnology 2004; 20(6): 559-562. http://dx.doi. org/10.1023/B:WIBI.0000043161.02154.57.

Ellis SR, Hodson ME, Wege P. The influence of different artificial soil types on the acute toxicity of carbendazim to the earthworm Eisenia fetida in laboratory toxicity tests. European Journal of Soil Biology 2007; 43: 239-245. http://dx.doi.org/10.1016/j.ejsobi.2007.08.023.

Freitas FC, Presotto RA, Genúncio GC, Amaral Sobrinho $\mathrm{NMB}$, Zonta E. pH, sódio, potássio, cálcio, magnésio e alumínio em solos contaminados com fluido de perfuração de poços de petróleo após ensaios de lixiviação. Ciência Rural 2015; 45(8): 1418-1423. http://dx.doi.org/10.1590/01038478 cr20140284.

Gomez-Eyles JL, Svendsen C, Lister L, Martin H, Hodson ME, Spurgeon DJ. Measuring and modeling mixture toxicity ofimid a clopridandthiaclo- prid on Caenorhabditis elegans and Eisenia fetida. Ecotoxicology and Environmental Safety 2009; 72(1): 71-79. http://dx.doi.org/10.1016/j. ecoenv.2008.07.006. PMid:18723220.

Guzyte G, Sujetoviene G, Zaltauskaite J. Effects of salinity on earthworm (Eisenia fetida). Environmental Engineering 2011; 1: 111-114

Hund-Rinke K, Wiechering H. Earthworm avoidance test for soil assessments. An alternative for acute and reproduction tests. Journal of Soils and Sediments 2001; 1: 15-20.

International Standard Organization - ISO. ISO 11268-2: soil quality - effects of pollutants on earthworms (Eisenia fetida). Part 2. Determination of Effects on Reproduction. Geneva: ISO; 1997.

International Standard Organization - ISO. ISO draft 238: soil quality - avoidance test for testing the quality soils and toxocity of chemical - Test with earthworms (Eisenia fetida). Geneva: ISO; 2003.

Langdon CJ, Piearce TG, Meharg AA, Semple KT. Inherited resistance to arsenate toxicity in two populations of Lumbricus rubellus. Environmental Toxicology and Chemistry 2003; 22(10): 2344-2348. http://dx.doi.org/10.1897/02-554. PMid:14551998.

Lima ESA, Amaral Sobrinho NMB, Magalhães MOL, Guedes JN, Zonta E. Absorção de bário por plantas de arroz (Oryza sativa l.) e mobilidade em solo tratado com baritina sob diferentes condições de potencial redox. Quimica Nova 2012; 35(9): 1746-1751. http://dx.doi. org/10.1590/S0100-40422012000900008.

Magalhães MOL, Amaral Sobrinho NMB, Lima ESA, Zonta E, Freitas FC. Efeito da aplicação e interação do cascalho de perfuração de poços de petróleo em solos intemperizados. In: Amaral Sobrinho NMB, Chagas CI, Zonta E, organizadores. Impactos ambientais provenientes da produção agrícola: experiências argentinas e brasileiras. São Paulo: Editora Livre Expressão; 2016.

Magalhães MOL, Amaral Sobrinho NMB, Zonta E, Becerra AT, Lastra-Bravo XB, Coutinho IB. Reducing conditions on barium absorption in rice plants cultured in $\mathrm{BaSO}_{4}$ enriched. Acta Scientiarum Agronomy (Impresso) 2014a; 36(1): 119-127. http://dx.doi.org/10.4025/actasciagron. v36i1.17539.

Magalhães MOL, Amaral Sobrinho NMB, Zonta E, Simões BF, Mattos AG, Tolón-Becerra A et al. The effects of oil well drill cuttings on soil and rice plant development (Oryza sativa) under two redox conditions. Bulletin of Environmental Contamination and Toxicology 2014b; 92(3): 311-316. http://dx.doi.org/10.1007/s00128-0141196-7. PMid:24414162.

Magalhães MOL, Amaral Sobrinho NMB, Zonta E, Carvalho MM, Tolón-Becerra A. Effect of variations in the redox potential of Gleysol on barium mobility and absorption in rice plants. Chemosphere (Oxford) 2012; 89(1): 121-127. http://dx.doi.org/10.1016/j.chemosphere.2012.04.060. PMid:22652443.

Magalhães MOL. Dinâmica do bário em solos contaminados por resíduos oriundos da perfuração de poços de petróleo [tese]. Seropédica: Universidade Federal Rural do Rio de Janeiro; 2011.

Organization for Economic Cooperation and Development - OECD. Guia para Testes Químicos, OECD 207. Paris: OECD; 1984. Acute Oral Toxicity-Acute Toxic Class Method. 
Owojori OJ, Reinecke AJ, Rozanov AB. Effects of salinity on partitioning, uptake and toxicity of zinc in the earthworm Eisenia fetida. Soil Biology and Biochemistry 2008; 40: 2385-2393.

Owojori OJ, Reinecke AJ. Avoidance behavior of two ecophysiologically different earthworms (Eisenia fetida and Aporrectodea caliginosa) in natural and artificial saline soils. Chemosphere 2009; 75(3): 279-283. http://dx.doi. org/10.1016/j.chemosphere.2008.12.051. PMid:19211128.

Sampaio J Jr, Amaral Sobrinho NMB, Magalhães MOL, Zonta E. Barium and sodium in sunflower plants cultivated in soil treated with wastes of drilling of oil well. Revista
Brasileira de Engenharia Agrícola e Ambiental 2015; 19(11): 1100-1106. http://dx.doi.org/10.1590/1807-1929/ agriambi.v19n11p1100-1106.

United States Environmental Protection Agency - USEPA. Method 3051A - microwave assisted acid digestion of sediments, sludges, soils, and oils. Revision 1. Washington: USEPA; 2007.

Wu B, Liu Z, Xu Y, Li D, Li M. Combined toxicity of cadmium and lead on the earthworm Eisenia fetida (Annelida, Oligochaeta). Ecotoxicology and Environmental Safety 2012; 81: 122-126. http://dx.doi.org/10.1016/j. ecoenv.2012.05.003. PMid:22608004. 